\title{
Double Track Program: Extracurricular Implementation to Increase Skill in Vocational High School
}

\author{
Joko Budi Santosa', Budi Santosa ${ }^{2}$, Fatwa Tentama ${ }^{2}$ \\ 1SMAN 1 Adipala, Jl. Jend. A. Yani, Bulujegang, Doplang, Cilacap 53211 Central Java, Indonesia \\ 2Universitas Ahmad Dahlan, Yogyakarta, Indonesia \\ *Corresponding author, e-mail: jokobudisantosa@yahoo.co.id
}

\begin{abstract}
The research was conducted aimed at knowing the effectiveness of the double-track program model applied to secondary school education in Cilacap Regency. The dual-track program model in question is a learning model that provides facilitation to high school students who will continue to college and also students who will look for work after graduating from school. This research was based on the number of high school graduates who do not go to college. There were $70 \%$ of students in the place of a study carried out students prefer to find work rather than continuing to college. This study uses the research and development (R \& D) method developed by Borg \& Gall and modified by Nana Syaodih Sukmadinata (2011), which consists of preliminary, development, and testing stages. This research was conducted at Adipala 1 Public High School, Cilacap Regency. Study at the research stage is the initial condition of research where the school has implemented vocational skills learning, then continued with the development stage by providing soft skills training. Furthermore, this research was carried out by testing the Focus Group Discussion (FGD) method by a team of experts from educational practitioners with respondents from several school principals, and the teacher in charge of the program. The results of research and development found that according to the perceptions and opinions of education experts who are members of the focus group discussion (FGD) showed that the dual-track program provides maximum service to students on two choices after graduating from school whether they want to go to college or seek employment. The dual-track program also provides increased student competency in vocational skills learning and soft skills competencies
\end{abstract}

Keywords: Double track program, Life skills, Soft skills, Vocational skills.

\section{INTRODUCTION}

Senior High School (SMA) is a form of secondary education unit that organizes a three-year education program. The aim of high school education is to support the achievement of national education goals, to educate the nation's life and develop Indonesian people as a whole, namely humans who: (1) believe and fear God Almighty, (2) noble character, (3) possess knowledge and skills, (4) physically and mentally healthy, (5) independent and robust personality, (6) having a sense of social and national responsibility (PP 19/2005).

The purpose of senior secondary education is to increase the knowledge of students to continue their education at a higher level and to develop themselves in line with the development of science and technology and improve the ability of students as members of society in conducting reciprocal relations with the surrounding social, cultural and natural environment. The high school education goals of senior high school graduates can continue to a higher level of education (PP 19/2005).

According to data from the Central Bureau of Statistics (BPS) in February 2018, the unemployment rate for high school graduates was 1,650,636 children, and for vocational students, there were 1,424,428 children. The Gross Enrollment Rate (APK) of high school students who continue to tertiary education is still very low $35 \%$ of students who continue to pursue tertiary education. It showed that the aim of senior secondary education had not been achieved well. It is necessary to have a creative idea from high school to provide 
supplies to students who do not continue their education so that they can also get a decent life (Rogeleonick, 2014).

In Cilacap district in 2016, job seekers based on the highest level of education also existed at the senior secondary level, with a total of 16,998 job seekers consisting of 10,132 male and 6,866 female workers. This fact shows that at the lower secondary level, they tend to find work, and only a few of them continue to pursue higher education. The unemployment rate was influenced by the level of education, especially high school/Aliyah graduates in Jombang Regency. Increased high school/'Aliyah graduates affect the magnitude of the unemployment rate (Suaidah, 2013).

In Cilacap district in 2016, job seekers based on the highest level of education also existed at the senior secondary level, with a total of 16,998 job seekers consisting of 10,132 male and 6,866 female workers. This fact shows that at the lower secondary level, they tend to find work, and only a few of them continue to pursue higher education. The unemployment rate was influenced by the level of education, especially high school/Aliyah graduates in Jombang Regency. Increased high school/'Aliyah graduates affect the magnitude of the unemployment rate (Suaidah, 2013).

There is a positive and significant relationship between academic self-confidence and vocational maturity, which shows that higher academic self-esteem, the higher professional maturity in students. Therefore conversely, the lower the academic confidence, the lower the vocational maturity in students (Purwandari, 2009).

Self-confidence in students was manifested in the provision of vocational skills and soft skills. By providing professional skills, students were expected to increase their confidence, so that they are more competent in entering the workforce (Gormally, 2009).

This research is necessary because it can make a significant contribution to the government. The result of the study will get a vocational learning model for high school students. Vocational education in high school is one solution to the many unemployed high school graduates. Vocational education will also equip high school graduates to have sufficient competencies to compete in the world of work.

\section{RESEARCH METHOD}

This research is research and development (R \& D) research with survey research design research (survey research) with the version of Sugiyono (Sugiyono, 2010). The steps of research and development refer to the experiments that have been conducted at Far West Laboratory, as quoted by Sukmadinata in his book (Sukmadinata, 2011). This research begins with the initial state of research results where the school where vocational skills learning research is conducted is given in extracurricular learning. Extracurricular learning is carried out outside school hours, with the curriculum refers to the education and training curriculum issued by the Directorate of Course Development and Institutional Affairs of the Ministry of National Education. Learning vocational skills provided are car steering, graphic design, computer accounting, and cosmetology.

From this initial situation, there are still obstacles for students to compete in the world of work. This is because students do not have maturity in soft skills, so students in competing in the world of work have several obstacles such as communication skills, ability to answer questions in interview tests. Students who have got jobs also have obstacles such as easy despair, difficulty adapting to the work environment, and other social constraints.

From this obstacle, the researcher developed the development stage, namely by providing soft skills training to all students. The soft skills training provided has to do with

Santosa, J. B., Santosa, B., \& Tentama, F. (2019). Double Track Program: Extracurricular Implementation to Increase Skill in Vocational High School. Journal of Vocational Education Studies, 2(1), 61-66. DOI: https://doi.org/10.12928/joves.v2i1.381. 
strengthening the competence of students to compete in the world of work and to minimize the obstacles that still exist.

The final stage of this research is testing the vocational skills learning model by experts and practitioners. Experts and practitioners in the world of education are given interview instruments with a number of questions about the vocational skills learning model that is applied in this research site. From the results of the interview, conclusions and suggestions were obtained as material to improve this research.

\section{RESULTS AND DISCUSSION}

The results of this study are vocational skills learning models coupled with soft skills training provide better maturity and confidence in students to enter the world of work for high school students who do not continue their studies.

\section{Planning Phase}

At this stage of implementation, the following steps are implemented: (1) Submission of ideas and ideas from researchers to the school development team. The school development team consists of principals, vice-principals, and senior teachers. (2) After the ideas and ideas were agreed upon, a team was formed to take care of the doubletrack program (3) Socialization of the double-track program to students, parents of students, and school members. (4) Cooperating with the Institute for Training and Training (LKP) and making Memorandum of Understanding (MoU).

\section{Implementation Phase}

\section{Extracurricular Stir Car}

Steering car learning is carried out in extracurricular activities carried out at hours outside of teaching and learning activities. Participants from the steering wheel program were selected because the number of applicants was more than the existing quota. The quota amount provided by the school is 20 participants. In the $2017 / 2018$ school year, the number of registrants was 62 students, and in the 2018/2019 second year, there were 65 students.

Extracurricular learning on the steering wheel is held every Saturday when students are off school. This learning works with the Institute for Training and Skills. This activity was funded by the School Operational Assistance (BOS) fund and with the Education Operational Assistance (BOP) fund from the Central Java Provincial Government. This learning activity can be seen in Figure 1.
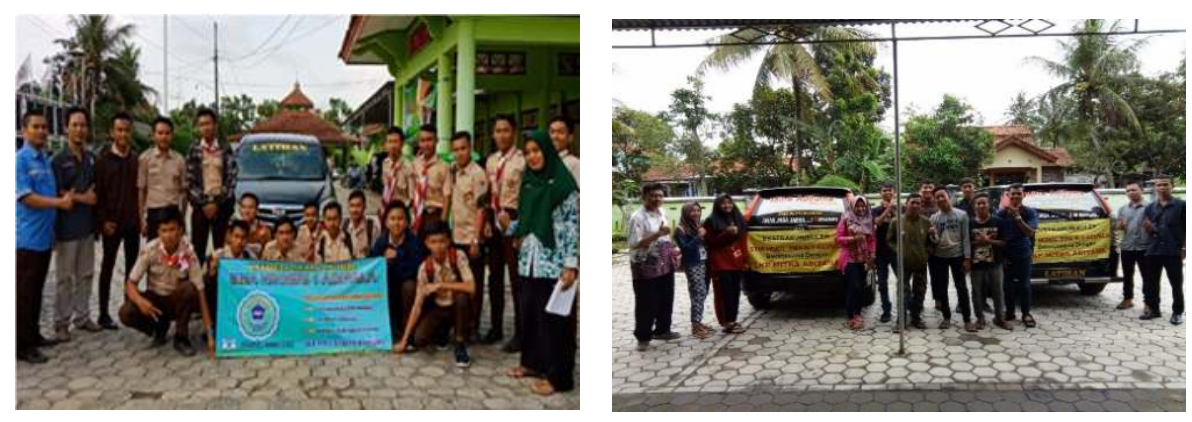

Figure 1. The steering wheel extracurricular learning activities.

Santosa, J. B., Santosa, B., \& Tentama, F. (2019). Double Track Program: Extracurricular Implementation to Increase Skill in Vocational High School. Journal of Vocational Education Studies, 2(1), 61-66. DOI: https://doi.org/10.12928/joves.v2i1.381. 
The steering wheel program is held for 12 meetings, with the duration of the car steering practice as much as 30 minutes each meeting. At the first meeting, students were given an introduction to the various functions and tools in the car. In this first meeting, students were also given the introduction of traffic signs and driving ethics.

\section{Extracurricular Graphic Design}

Graphic design extracurricular activities are held on holidays, ie, every Saturday. This learning was carried out in collaboration with LK Aditama LKP. Learning is held 12 times and ends with a competency exam. Students who pass the competency test get a certificate issued by the LKP. The certificate can be used for conditions to find a job. This extracurricular activity is carried out, as shown in Figure 2.

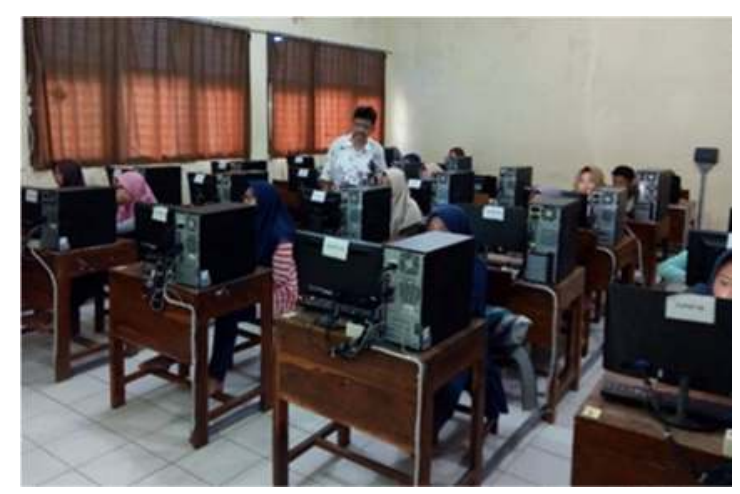

Figure 2. Graphic design, extracurricular learning activities.

\section{Extracurricular Accounting Computer}

Accounting computer extracurricular activities are held on holidays, ie, every Saturday. This learning was carried out in collaboration with LK Aditama LKP. Learning is held 12 times and ends with a competency exam. Students who pass the competency test get a certificate issued by the LKP. The certificate can be used for conditions to find a job. This extracurricular activity is carried out, as shown in Figure 3.

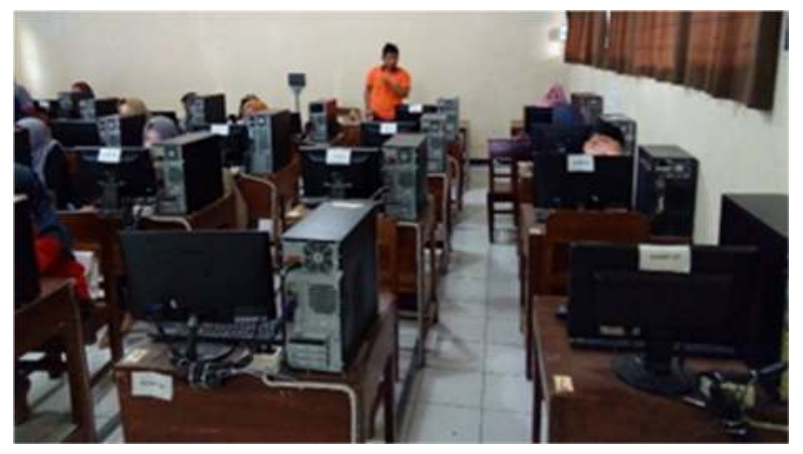

Figure 3. Graphic design, extracurricular learning activities.

\section{Extracurricular Makeup}

Extracurricular activities for make-up are carried out on holidays, namely every Saturday and Sunday. This learning is carried out in collaboration with a beauty salon. Learning is held 12 times and ends with a competency exam. Students who pass the

Santosa, J. B., Santosa, B., \& Tentama, F. (2019). Double Track Program: Extracurricular Implementation to Increase Skill in Vocational High School. Journal of Vocational Education Studies, 2(1), 61-66. DOI: https://doi.org/10.12928/joves.v2i1.381. 
competency test get a certificate issued by the LKP. The certificate can be used for conditions to find a job.

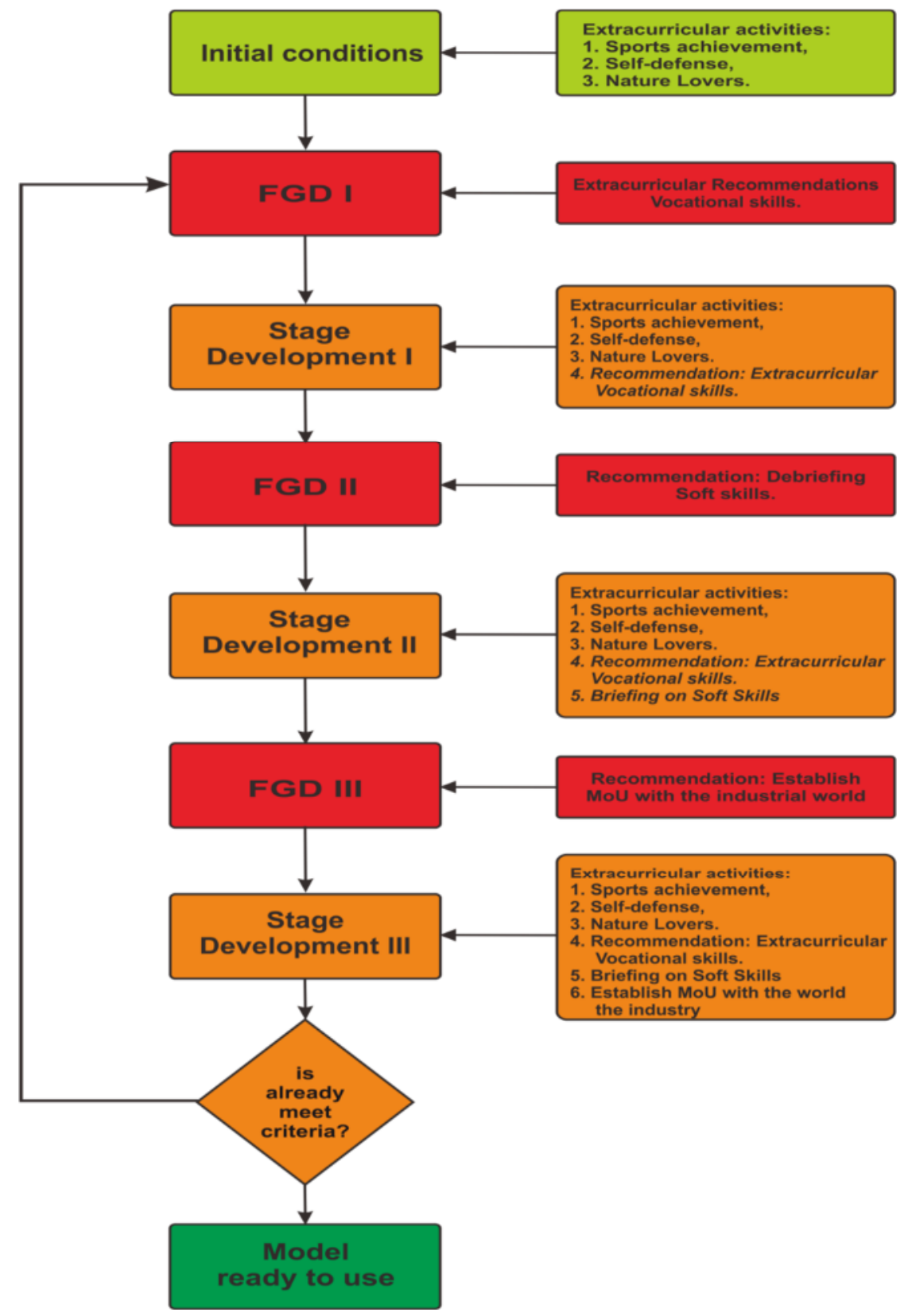

Figure 4. Research scheme

\section{Evaluation Phase}

In the double-track evaluation phase, the program was studied in depth through focus group discussion (FGD) and practitioner assessment so that it became a vocational skills learning model that could be applied in high school. The FGD was held on Monday, November 19, 2018, at 09.00 - 11.00 WIB in the principal's room at Adipala 1 Public High School, Cilacap Regency. The FGD participants are 10 (ten) people consisting of school principals 1 (one), namely the Head of Adipala 1 High School. From the element of the

Santosa, J. B., Santosa, B., \& Tentama, F. (2019). Double Track Program: Extracurricular Implementation to Increase Skill in Vocational High School. Journal of Vocational Education Studies, 2(1), 61-66. DOI: https://doi.org/10.12928/joves.v2i1.381. 
vice-principal, 4 (four) people consist of the deputy headmaster of the affairs of the curriculum, public relations, student affairs, and infrastructure. From the elements in charge of the program, there are 3 (three), namely, the person in charge of the extracurricular steering wheel, graphic design/computer accounting, and makeup. There are 2 (two) extracurricular resource persons from the vocational teacher elements and from soft skills trainers.

From the FGD discussion forum, it was recommended that vocational skills learning be complemented by soft skills learning. Learning soft skills is very important given to students because soft skills competency is a very big role in student success. Overall the stages of this research starting from the research stage to the development stage can be described through the scheme in Figure 4.

\section{CONCLUSION}

The results of research and development found that according to the perceptions and opinions of education experts who are members of the focus group discussion (FGD) showed that the double track program provides maximum service to students on two choices after graduating from school whether they want to go to college or seek employment. The double track program also provides increased student competency in vocational skills learning and soft skills competencies.

\section{REFERENCES}

Gormally. (2009). Effects of inquiry-based learning on students' science literacy skills and confidence. International journal for the scholarship of teaching and learning, 3(2), 16.

PP.Nomor-19_tahun_2005. (2005). Peraturan Pemerintah Nomor 19 Tahun 2005.

Purwandari, A. (2009). Kematangan vokasional pada siswa kelas XII di SMA Negeri 1 Klaten ditinjau dari keyakinan diri akademik dan jenis kelas. Universitas Diponegoro.

Rogeleonick, A. (2014). Target 2015, Angka Partisipasi Kasar Perguruan Tinggi 35 Persen.

Suaidah, I. (2013). Pengaruh Tingkat Pendidikan Terhadap Tingkat Pengangguran Di Kabupaten Jombang. Jurnal Pendidikan Ekonomi (JUPE), 1(3).

Sugiyono. (2010). Metode Penelitian Kuantitatif, Kualitatif, dan R\&D. Bandung: CV Alfabeta.

Sukmadinata, N. S. (2011). Metode penelitian pendidikan: Penelitian memberikan deskrepsi, eksplanasi, prediksi, inovasi, dan juga dasar-dasar teoretis bagi pengembangan pendidikan. Bandung: Program Pascasarjana Universitas Pendidikan Indonesia-PT Remaja Rosdakarya.

Santosa, J. B., Santosa, B., \& Tentama, F. (2019). Double Track Program: Extracurricular Implementation to Increase Skill in Vocational High School. Journal of Vocational Education Studies, 2(1), 61-66. DOI: https://doi.org/10.12928/joves.v2i1.381. 